\title{
Probiotic Yogurt Culture Bifidobacterium Animalis Subsp. Lactis BB-12 and Lactobacillus Acidophilus LA-5 Modulate the Cytokine Secretion by Peripheral Blood Mononuclear Cells from Patients with Ulcerative Colitis
}

Authors

Affiliations
A. Sheikhi' ${ }^{1,2}$, M. Shakerian ${ }^{3}$, H. Giti ${ }^{4}$, M. Baghaeifar ${ }^{3}$, A. Jafarzadeh ${ }^{5}$, V. Ghaed ${ }^{1}$, M. R. Heibor ${ }^{1}$, N. Baharifar ${ }^{6}$, Z. Dadafarin ${ }^{7}$, G. Bashirpour ${ }^{8}$

Affiliation addresses are listed at the end of the article
Key words

immunomodulation

ulcerative colitis

- bifidobacterium lactis

- lactobacillus acidophilus

probiotics received 26.11.2015 accepted 17.01.2016

\section{Bibliography}

Dol http://dx.doi.org/

10.1055/s-0035-1569414

Published online:

February 24, 2016

Drug Res 2016;

66: 300-305

(c) Georg Thieme Verlag KG

Stuttgart · New York

ISSN 2194-9379

Correspondence

\section{A. Sheikhi}

Associate Professor of

Immunology

Department of Immunology

Faculty of Medicine

Dezful University of Medical

Sciences

Azadegan, Dezful

Iran

Post code: 6461945914

Tel.: + 98/61/42429 733

Fax: + 98/61/42429 538

sheikhi.a@dums.ac.ir

sheikhi@queensu.ca

\section{Abstract}

$\nabla$

Background: There are some evidences for the immunomodulation disorders in the response to intestinal microbiota in inflammatory bowel disease. Yogurt is a fermented milk product made with a starter culture consisting of different probiotics which could be colonized in intestine. However, the role of probiotics in the aetiopathogenesis of ulcerative colitis (UC) has not been clarified. To determine how the immune system responds to these bacteria this study was planned.

Methods: Bifidobacterium lactis BB-12 (B. lactis) and Lactobacillus acidophilus LA-5 (L. acidophilus) were cultivated on MRS broth. PBMCs of 36 UC patients were separated by FicollHypaque centrifugation and co-cultured with different concentrations of UV killed bacteria in RPMI- 1640 plus $10 \%$ FCS for $48 / 72$ h. IL-10, TGF-

\section{Introduction}

$\nabla$

Ulcerative colitis (UC) as one of the 2 major forms of inflammatory bowel disease (IBD) is a chronic and relapsing inflammatory condition that is characterized by colonic tissue edema, increased colonic epithelial permeability and extensive infiltration of leukocytes in the colon and rectum [1]. It is a cause of significant morbidity worldwide and its incidence and prevalence appear to be increasing with time. Patients with UC frequently experience episodes of bloody diarrhea with or without mucous, abdominal pain, fever and weight loss [2].

UC is assumed to be a result of a breakdown of tolerance to intestinal environmental antigens such as resident enteric bacteria. Several species of bacteria are living in human gastrointestinal lumen [3], which main sources of them are fermented foods containing probiotics, such as $\beta$, IFN- $\gamma$ and TNF- $\alpha$ were measured in supernatant of PBMCs by ELISA.

Results: Both bacteria significantly augmented IL-10, TGF- $\beta$, IFN- $\gamma$ and TNF- $\alpha$ compared to control $(p<0.001)$. The secretion levels of IL-10 and TGF- $\beta$ by B. lactis- compared to L. acidophilusstimulated PBMCs were significantly higher $(\mathrm{p}<0.05, \mathrm{p}<0.01$ respectively). The secretion levels of TNF- $\alpha$ and IFN- $\gamma$ by PBMCs after $72 \mathrm{~h}$ were significantly lower compared to $48 \mathrm{~h}$ stimulation by B. lactis ( $\mathrm{p}<0.001, \mathrm{p}<0.035$ respectively).

Conclusion: These data show that both probiotics may trigger the pro- and anti-inflammatory immune response of UC patients. It seems that IL-10/TGF- $\beta$ uprising by $B$. lactis could be the reason of TNF- $\alpha /$ IFN- $\gamma$ reduction. Therefore albeit B. lactis still stimulates the effector Th cells but because of more stimulatory effect on Tregs, it could be a good potential therapeutic candidate for further investigation.

yogurt [4]. Some studies suggest that different species have variable potential to stimulate regulatory or effector $\mathrm{T}$ cells in the mucosal immune system [5, 6]. Indeed, cytokine profiles in co-cultures of the probiotic bacteria with peripheral blood mononuclear cells (PBMC) show marked differences between strains [7].

Upon antigenic stimulation, the T CD4 + cells differentiate into several subsets such as Th1, Th2, Th17 and regulatory $\mathrm{T}$ (Treg) cells which are characterized by distinct cytokine profile $[8,9]$. Treg cells are poised with regulatory activity limiting the development of T-cell responses to intestinal commensal bacteria and the development of pathologic intestinal inflammation. Evidence indicate the Th1 (such as IFN- $\gamma$ and TNF- $\alpha$ ), Th2 (IL-4, IL-5, IL-13) and Th17 (IL-17A) (all effector Th)-related cytokines could lead to UC disease progression and worsening of symptoms whereas the Treg-related cytokines (TGF- $\beta$ and IL-10) 
have been associated with the reduction and improvement of symptoms in UC patients $[10,11]$. Recent evidences have indicated that probiotic treatment has a great influence on the host intestinal immune system to control inflammation $[12,13]$.

The aim of this study is to find whether B. lactis BB-12 and L. acidophilus LA-5, as probiotic strains used as dietary supplements in yogurt, differ in their capacity to induce Treg- or effector Th related cytokines in PBMCs from UC patients.

\section{Materials and Methods}

$\nabla$

\section{Patients}

The study included 36 inactive UC patients (21 male and 15 female; $32.5 \pm 10.4$ years of age). Diagnosis of UC had been established based upon endoscopic and histological criteria as well as clinical symptoms. The patients have no complications or history of immunological disorders other than UC. None of the patients had received glucocorticoids, cyclosporine, or tacrolimus for at least 2 months prior to the study. The study was approved by Ethical Committee of Dezful University of Medical Sciences.

\section{Isolation of peripheral blood mononuclear cells}

After informed consent was obtained, $10 \mathrm{ml}$ of heparinized venous blood was taken from patients with UC. The heparinized blood was loaded on $3 \mathrm{ml}$ of Ficoll-Hypaque (Pharmacia), centrifuged at $1300 \times \mathrm{g}$ for $20 \mathrm{~min}$, and PBMCs were separated as described previously [14-17].

Breifly, the cells were washed 3 times with phosphate buffered saline (PBS), resuspended in RPMI 1640 media (Gibco), supplemented with $10 \%$ heat-inactivated fetal calf serum (FCS), $100 \mathrm{U} /$ $\mathrm{mL}$ penicillin, $100 \mu \mathrm{g} / \mathrm{mL}$ streptomycin (Gibco), and cultured at $37^{\circ} \mathrm{C}$ in a humidified $5 \% \mathrm{CO} 2$ incubator to a final density of $2 \times 10^{6}$ cells $/ \mathrm{ml}$.

\section{Preparation of bacterial strains}

Lactobacillus (L) acidophilus LA-5 and Bifidobacterium (B) lactis BB-12 were kindly provided by Sherkat Pegah Khuzestan, Dezful, Iran. Strains were cultured in de Man, Rogosa and Sharpe (MRS) broth (Merck, Darmstadt, Germany) at $37^{\circ} \mathrm{C}$ under anaerobic jars for $48 \mathrm{~h}$. All bacteria were harvested by centrifugation (3000g for $15 \mathrm{~min}$ ) during stationary growth phase.

Pelleted bacteria were then washed 3 times in PBS, concentration was determined by colony-forming unit (CFU) counting, and diluted to a final working concentration of $10^{8} \mathrm{CFU} / \mathrm{mL}$ in RPMI 1640. This stock suspension was aliquoted and stored at $-20^{\circ} \mathrm{C}$. To inhibit uncontrolled bacterial growth, ultraviolet (UV) inactivation was done by placing an aliquot in wells of a 48 -well culture plate and placing the plate $4 \mathrm{~cm}$ from a UV light source for $40 \mathrm{~min}$. Samples were then tested for inactivity by culturing on MRS agar compared to live bacteria sample. UVkilled bacteria have a preserved structural integrity, in contrast to heat-inactivated bacteria.

\section{The measurement of TNF- $\alpha$, IFN- - , IL-10 and IL-1 $\beta$ secretion}

After the incubation of PBMCs $\left(2 \times 10^{5}\right.$ cells/well $)$ with different concentrations of (in a cell:bacteria ratio of 1:100 and 1:50) killed L. acidophilus LA-5 and B. lactis BB-12 strains (or RPMI-1640 as control) for 48 and $72 \mathrm{~h}$, the supernatant was aspirated and the TNF- $\alpha$, IFN- $\gamma$, IL-10 and TGF- $\beta$ levels were measured using sandwich ELISA (Quantikine, R\&D Systems, Minneapolis, MN).

\section{Statistical analysis}

Results were expressed as mean \pm SD. Differences in mean values between groups were analyzed with Student's t-test to reveal significant differences between cytokine production in response to different strains of bacteria. Differences were considered to be significant at $\mathrm{P}<0.05$. Statistical calculations were performed with SPSS 19 (SPSS Inc., Chicago, IL, USA).

\section{Results \\ $\nabla$}

Effect of B. lactis on pro-inflammatory and regulatory cytokines

As shown in $\odot$ Table 1, B. lactis significantly upraised IL-10 and TGF- $\beta$ secretion by PBMCs in a dose- and time dependent-manner compared to control cultures $(p<0.001)$ ( $\odot$ Fig. 1a-d). The secretion levels of TNF- $\alpha$ and IFN- $\gamma$ by B. lactis stimulated PBMCs at $72 \mathrm{~h}$ was significantly lower as compared to $48 \mathrm{~h}$ time(TNF- $\alpha$ : $\mathrm{p}<0.001$ IFN- $\gamma: \mathrm{p}<0.035$ ) ( $\odot$ Fig. $2 \mathrm{a}-\mathbf{d}$ ). This reduction could be due to immunomodulatory effects of the augmented IL-10 and TGF- $\beta$ after $72 \mathrm{~h}$ compared to $48 \mathrm{~h}$ incubation time ( $\odot$ Fig. 1a-d). The secretion levels of TNF- $\alpha$ and IFN- $\gamma$ after stimulation of PBMCs by $B$. lactis at 100:1 bacteria:cells ratio was significantly lower than 50:1 bacteria:cells ratio ( $p<0.001)$ ( $\odot$ Fig. $2 a-d)$. As it is shown in $\odot$ Fig. 1a-d this reduction could be due to the immunomodulatory effects of the augmented IL-10 and TGF- $\beta$ at 100:1 compared to $50: 1$ bacteria:cells ratio.

At $48 \mathrm{~h}$ of incubation time, the secretion levels of IFN- $\gamma$ by PBMCs in the presence of the 50:1 bacteria:cells ratio of $\mathrm{B}$. lactis were

Table 1 Evaluation of TNF $\alpha$, IFN- $\gamma$, TGF- $\beta$ and IL-10 secretion by PBMCs of Ulcerative Colitis patients by ELISA method.

\begin{tabular}{|c|c|c|c|c|c|c|c|c|c|}
\hline & \multirow[b]{2}{*}{ Bacteria: Cell } & \multicolumn{2}{|c|}{$\begin{array}{c}\text { IFN-v (pg/ml) } \\
\text { Mean } \pm \text { SD }\end{array}$} & \multicolumn{2}{|c|}{$\begin{array}{c}\text { TNF- } \alpha(p g / m l) \\
\text { Mean } \pm S D\end{array}$} & \multicolumn{2}{|c|}{$\begin{array}{c}\text { IL-10 }(\mathrm{pg} / \mathrm{ml}) \\
\text { Mean } \pm \text { SD }\end{array}$} & \multicolumn{2}{|c|}{$\begin{array}{c}\text { TGF- } \beta(p g / m l) \\
\text { Mean } \pm \text { SD }\end{array}$} \\
\hline & & $48 \mathrm{~h}$ & $72 \mathrm{~h}$ & $48 \mathrm{~h}$ & $72 \mathrm{~h}$ & $48 \mathrm{~h}$ & $72 \mathrm{~h}$ & $48 \mathrm{~h}$ & $72 \mathrm{~h}$ \\
\hline Bifidobacterium & $100: 1$ & $1320 \pm 341$ & $1556 \pm 382$ & $2071 \pm 452$ & $2463 \pm 484$ & $510 \pm 253$ & $824 \pm 275$ & $611 \pm 284$ & $711 \pm 290$ \\
\hline $\begin{array}{l}\text { lactis + Lactoba- } \\
\text { cillus acidophilus }\end{array}$ & $50: 1$ & $1046 \pm 322$ & $1177 \pm 292$ & $1561 \pm 381$ & $2072 \pm 426$ & $317 \pm 171$ & $498 \pm 268$ & $472 \pm 164$ & $566 \pm 168$ \\
\hline Bifidobacterium & $100: 1$ & $588 \pm 228$ & $505 \pm 213$ & $1486 \pm 380$ & $822 \pm 366$ & $756 \pm 191$ & $1198 \pm 487$ & $1422 \pm 401$ & $1777 \pm 409$ \\
\hline lactis & $50: 1$ & $833 \pm 270$ & $648 \pm 177$ & $1888 \pm 561$ & $1067 \pm 392$ & $630 \pm 254$ & $953 \pm 303$ & $923 \pm 320$ & $1195 \pm 398$ \\
\hline Lactobacillus & $100: 1$ & $1444 \pm 365$ & $2061 \pm 388$ & $2171 \pm 531$ & $2687 \pm 553$ & $473 \pm 214$ & $563 \pm 250$ & $276 \pm 165$ & $341 \pm 164$ \\
\hline acidophilus & $50: 1$ & $1073 \pm 305$ & $1419 \pm 438$ & $1754 \pm 476$ & $2173 \pm 546$ & $315 \pm 167$ & $416 \pm 233$ & $228 \pm 165$ & $284 \pm 163$ \\
\hline Control & - & $152 \pm 59$ & $216 \pm 91$ & $229 \pm 109$ & $335 \pm 118$ & $97 \pm 61$ & $132 \pm 76$ & $59 \pm 35$ & $73 \pm 38$ \\
\hline
\end{tabular}

$\mathrm{SD}=$ standard deviation 
significantly lower $(P<0.05)$ whereas the secretion levels of IL-10 and TGF- $\beta$ were significantly higher $(P<0.001$ and $\mathrm{P}<0.0001$, respectively) as compared with the stimulation of PBMCs with L. acidophilus in the same time and same bacteria:cells ratio.

Similarly, at $48 \mathrm{~h}$ of incubation time, the secretion levels of IFN- $\gamma$ by PBMCs in the presence of the $50: 1$ bacteria:cells ratio of $B$. lactis were significantly lower $(\mathrm{P}<0.05)$ whereas the secretion levels of IL-10 and TGF- $\beta$ were significantly higher $(\mathrm{P}<0.002$ and $\mathrm{P}<0.001$, respectively) as compared with the stimulation of PBMCs with mixed probiotics in the same time and same bacteria:cells ratio.
At $48 \mathrm{~h}$ of incubation time, the secretion levels of IFN- $\gamma$ and TNF- $\alpha$ by PBMCs in the presence of the $100: 1$ bacteria:cells ratio of $\mathrm{B}$. lactis were significantly lower $(\mathrm{P}<0.0001$ and $\mathrm{P}<0.001$, respectively) whereas the secretion levels of IL-10 and TGF- $\beta$ were significantly higher $(\mathrm{P}<0.003$ and $\mathrm{P}<0.0001$, respectively) as compared with the stimulation of PBMCs with L. acidophilus in the same time and same bacteria:cells ratio.

The same results were obtained with mixed probiotics in the same time and same bacteria:cells ratio.

At $72 \mathrm{~h}$ of incubation time, the secretion levels of IFN- $\gamma$ by PBMCs in the presence of the 50:1 bacteria:cells ratio of $\mathrm{B}$. lactis were significantly lower $(\mathrm{P}<0.0001)$ whereas the secretion levels of
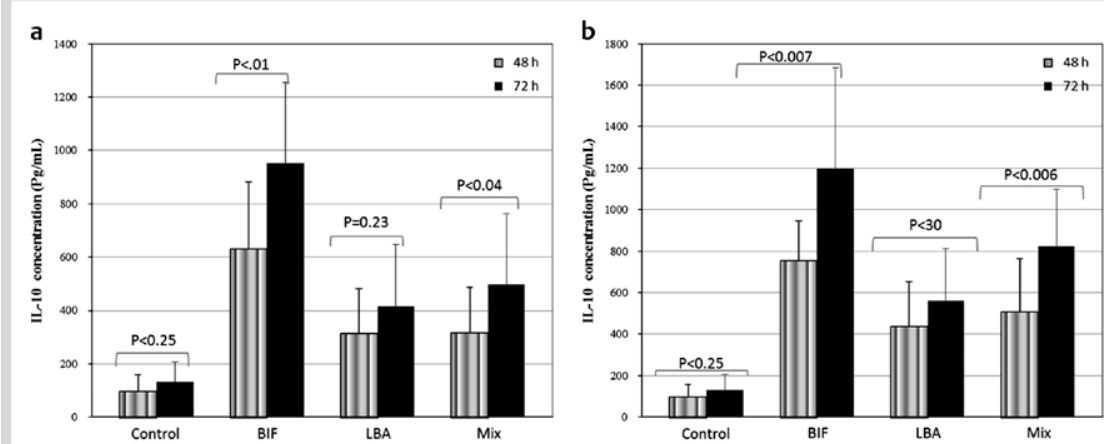

d

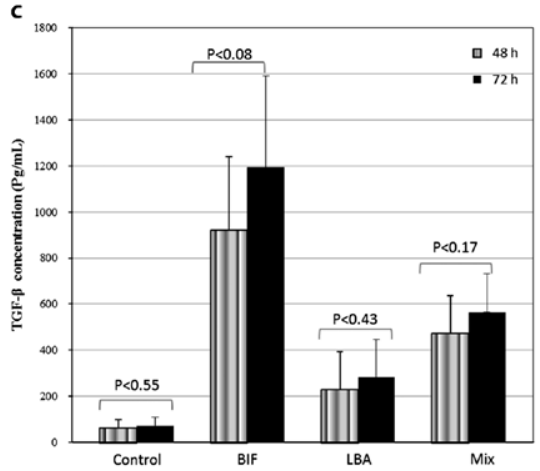

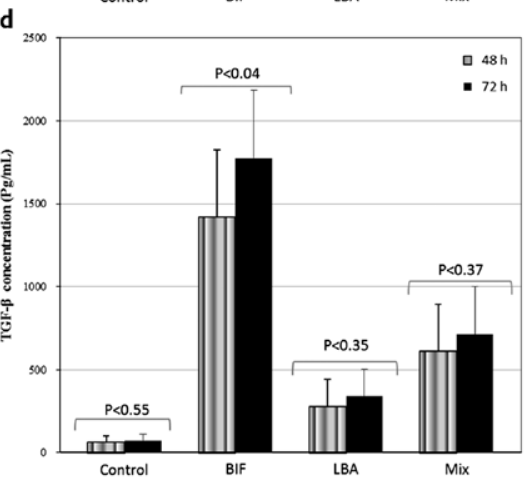

Fig. 1 a Effects of probiotics on the IL-10 secretion by PBMC the cell:bacteria ratio of 1:50. At 48 or $72 \mathrm{~h}$ of incubation times and in the cell:bacteria ratio of 1:50 B lactis, $L$ acidophilus or both probiotics significantly enhance the production of IL-10 by PBMCs compared to control $(P<0.001)$. b Effects of probiotics on the IL-10 secretion by PBMC the cell:bacteria ratio of $1: 100$. At 48 or $72 \mathrm{~h}$ of incubation times and in the cell:bacteria ratio of 1:100 B lactis, $L$ acidophilus or both probiotics significantly enhance the production of IL-10 by PBMCs compared to control $(P<0.001)$. $c$ Effects of probiotics on the TGF- $\beta$ secretion by PBMC the cell:bacteria ratio of $1: 50$. At 48 or $72 \mathrm{~h}$ of incubation times and in the cell:bacteria ratio of 1:50 B. lactis, L. acidophilus, or both probiotics significantly enhance the production of TGF- $\beta$ by PBMCs compared to control $(P<0.001)$. d Effects of probiotics on the TGF- $\beta$ secretion by PBMC the cell:bacteria ratio of $1: 100$. At 48 or $72 \mathrm{~h}$ of incubation times and in the cell:bacteria density of 1:100 B. lactis, L. acidophilus, or both probiotics significantly enhance the production of TGF- $\beta$ by PBMCs compared to control $(\mathrm{P}<0.001)$.
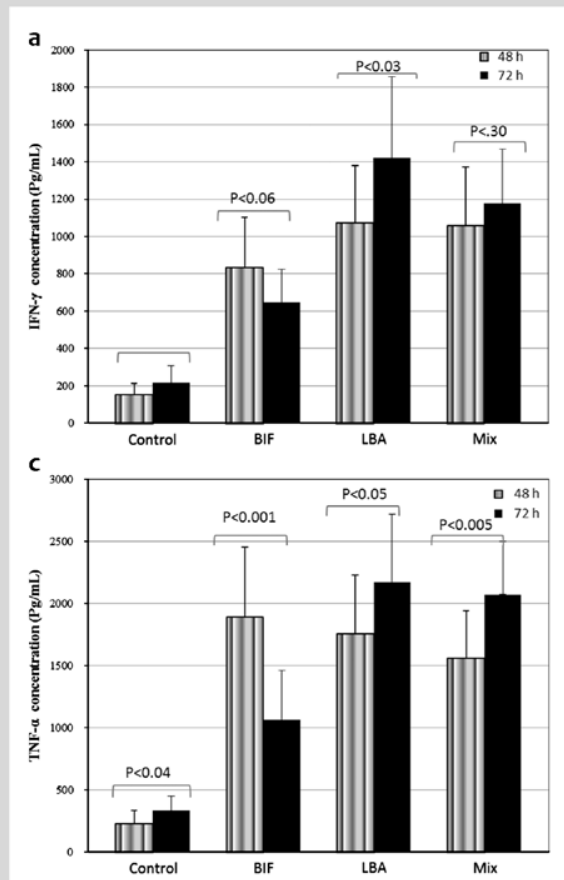

\section{b}

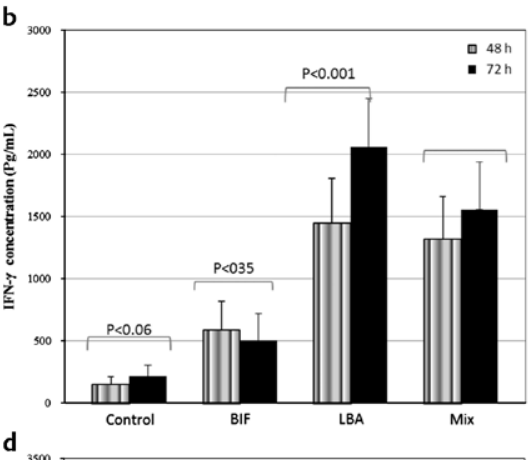

d

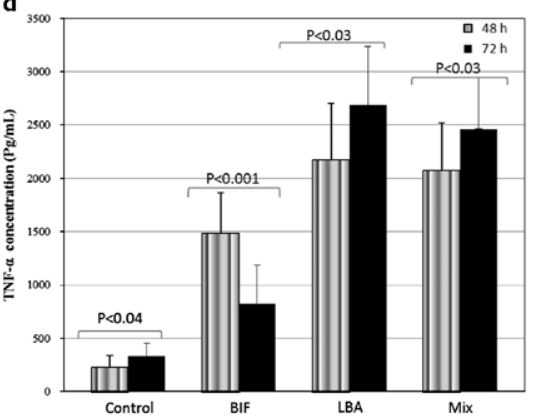

Fig. 2 a Effects of probiotics on the IFN-y secretion by PBMC the cell:bacteria ratio of $1: 50$. At 48 or $72 \mathrm{~h}$ of incubation times and in the cell:bacteria ratio of 1:50 B. lactis, L. acidophilus or both probiotics significantly enhance the production of IFN- $y$ by PBMCs compared to control $(\mathrm{P}<0.001)$. b Effects of probiotics on the IFN- $y$ secretion by PBMC the cell:bacteria ratio of $1: 100$. At 48 or $72 \mathrm{~h}$ of incubation times and in the cell:bacteria ratio of 1:100 B. lactis, L. acidophilus or both probiotics significantly enhance the production of IFN-y by PBMCs compared to control $(P<0.001)$. c Effects of probiotics on the TNF- $\alpha$ secretion by PBMC the cell:bacteria ratio of $1: 50$. At 48 or $72 \mathrm{~h}$ of incubation times and in the cell:bacteria ratio of 1:50 B. lactis, L. acidophilus or both probiotics significantly enhance the production of TNF- $\alpha$ by PBMCs compared to control $(P<0.001)$. d Effects of probiotics on the TNF- $\alpha$ secretion by PBMC the cell:bacteria ratio of $1: 100$. At 48 or $72 \mathrm{~h}$ of incubation times and in the cell:bacteria ratio of 1:100 B. lactis, L. acidophilus or both probiotics significantly enhance the production of TNF- $\alpha$ by PBMCs compared to control $(\mathrm{P}<0.001)$. 
IL-10 and TGF- $\beta$ were significantly higher $(\mathrm{P}<0.0001)$ as compared with the stimulation of PBMCs with L. acidophilus or mixed probiotics in the same time and same bacteria:cells ratio. The same results were obtained in the presence of the 100:1 bacteria:cells ( $\odot$ Fig. 1,2).

\section{Effect of L. acidophilus on pro-inflammatory and regulatory cytokines}

L. acidophilus upraised TNF- $\alpha$, IFN- $\gamma$, IL- 10 and TGF- $\beta$ by PBMCs in a dose- and time-dependent manner in comparison with control cultures $(p<0.001)$ ( $\odot$ Table 1$)$. The secretion levels of IL-10 and TGF- $\beta$ after stimulation of PBMCs by $L$. acidophilus were significantly lower as compared to B. lactis and mixed bacteria, totally (at 2 different incubation times and 2 different cells:bacteria ratios) $(p<0.05)$ ( $\bullet$ Fig. 1a-d). The secretion levels of TNF- $\alpha$ and IFN- $\gamma$ after stimulation of PBMCs by L. acidophilus were significantly higher in comparison to $\mathrm{B}$. lactis and mixed bacteria, totally (at 2 different incubation times and 2 different cells:bacteria ratios) $(\mathrm{p}<0.05)$ ( $\Theta$ Fig. $2 \mathrm{a}-\mathbf{d})$. This difference could be a result of the lower secretion of the mentioned immunoregulatory cytokines by L. acidophilus compared to B. lactis.

\section{Effect of mixed bacteria on pro-inflammatory and regulatory cytokines}

The mixed bacteria significantly influenced the secretion of TNF$\alpha$, IFN- $\gamma$, IL-10 and TGF- $\beta$ by PBMCs in a manner of dose- and time-dependent manner in comparison with control cultures $(p<0.001)$ ( $\bullet$ Table 1). The secretion levels of TNF- $\alpha$ and IFN- $\gamma$ were significantly higher after stimulation of PBMCs by mixed bacteria, as compared to B. lactis, totally (at 2 different incubation times and 2 different cells:bacteria ratios) were significantly lower as compared to L. acidophilus ( $\mathrm{p}<0.05$ and $\mathrm{p}<0.05$ respectively) ( $\bullet$ Fig. 2a-d). Furthermore, the secretion levels of IL-10 and TGF- $\beta$ after stimulation of PBMCs by mixed bacteria was significantly lower in comparison to B. lactis, but were higher as compared to $\mathrm{L}$. acidophilus ( $\mathrm{p}<0.05$ and $\mathrm{p}<0.05$ respectively) (० Fig. 1a-d).

\section{Discussion}

$\nabla$

Although the immunopathogenesis of ulcerative colitis (UC) remains unclear, current evidence indicates that altered $\mathrm{T}$ cell response to intestinal environmental antigens such as resident commensal bacteria plays an important role [18-20]. So that an increased mucosal infiltration of activated CD4 + lymphocytes, dysfunctional dendritic cells, dysregulated macrophage-induced immune responses and abnormalities in regulatory pathways have been demonstrated $[21,22]$. Conventional therapies of UC, including corticosteroids, 5-ASA and thiopurines [23], were performed to reduce inflammation but do not change the natural course of disease, and many patients become refractory to conventional therapies during the course of the disease.

Recently, probiotic therapy has been considered to be potentially effective and safe in patients with UC. It's been reported that individual probiotic species have variable potential to stimulate regulatory or effector $\mathrm{T}$ cells in the mucosal immune system. Indeed, cytokine profiles in co-cultures of the probiotic bacteria with peripheral blood mononuclear cells (PBMC) show marked differences between strains [24].

In the present study we found that the mixed (B. lactis plus $\mathrm{L}$. acidophilus) bacteria strongly modulate the secretion of IL-10,
TGF- $\beta$, IFN- $\gamma$ and TNF- $\alpha$ in a manner of dose and time-dependent in comparison with control PBMCs. The amount of secreted TNF- $\alpha$ and IFN- $\gamma$ by PBMCs after stimulation by mixed bacteria were less than $\mathrm{L}$. acidophilus but more than B. lactis. These results indicate that B. lactis acts as a weak stimulator of PBMCs as compared to L. acidophilus.

Although the secretion of IL-10 and TGF- $\beta$ after stimulation by L. acidophilus were upraised, however, the secretion of IL-10 and TGF- $\beta$ by B. lactis stimulated- PBMCs were significantly higher in comparison to L. acidophilus and mixed bacteria. Higher levels of IL- 10 and TGF- $\beta$ may be a reason for the lower secretion levels of TNF- $\alpha$ and IFN- $\gamma$ after stimulation of PBMCs by B. lactis, compared to L. acidophilus and mixed bacteria. Although we did not use blocking antibodies to IL-10 and/or TGF to demonstrate whether these cytokines are suppressing IFN and TNF production, these results still as a valuable data indicate that $\mathrm{B}$. lactis could be a better candidate for Treg stimulation in comparison with L. acidophilus and mixed bacteria in UC patients.

Our results are in accordance with some previous studies. Akemi Imaoka et al. showed the secretion levels of IL-10 in the cultures of PBMCs isolated from the UC patients with heat-killed Bifidobacterium were higher as compared control cultures in the absence of probiotic bacteria [25]. Kato et al. showed that administration of Bifidobacterium-fermented milk for patients significantly reduced the clinical activity index after 12 weeks as compared with the control group [26]. Moreover, Peran L. et al. in an experimental study to compare the preventative effects exerted by B. lactis and L. acidophilus, in the trinitrobenzenesulphonic acid model of rat colitis showed when B. lactis was administered to colitic rats, a significant reduction in colonic TNF- $\alpha$ production was observed, whereas L. acidophilus administration significantly reduced colonic LTB4 production in the inflamed colon in comparison with untreated colitic rats [27]. Although still incompletely characterized, several reports indicate that the cytokine profile in UC patients is complex and seems to involve a variety of cytokines, as demonstrated by increased mRNA expression of IFN- $\gamma$, IL-13, IL-17 A, IL-4, IL-5, IL-1b, IL-6, IL-8 and TNF- $\alpha$ which are categorized under 3 kinds of effector Th: Th1 (IFN- $\gamma$, TNF- $\alpha$ ), Th2 (IL-4, IL-5, IL-13) and Th17 (IL-17 A) and innate immune responses (TNF, IL-1b, IL-6 and IL-8) [28-32].

Studies have demonstrated that anti-TNF therapy resulted in down-regulation of mucosal TNF- $\alpha$ and IFN- $\gamma$ mRNA expression in UC patients but therapy failure was positively associated with high mucosal mRNA expression of IFN- $\gamma[33,34]$. Increased expression of TNF- $\alpha$ and IFN- $\gamma$ mRNA has been detected not only in active UC but also in inactive UC, suggesting that these cytokines play a pivotal role in relapse of UC $[11,35]$.

Thus, it seems that high IFN- $\gamma$ and TNF- $\alpha$ as pro-inflammatory cytokines have important role in mucosal inflammation and it suggests that suppression of them could have important role in the successful treatment of UC. So, in the present study we measured these 2 pro-inflammatory cytokines as the sign of effector Th stimulatory potential of B. lactis and L. acidophilus. On the other hand, evidence has shown that non-functional, absent Tregs or genetic mutations in Foxp3 induces hypersensitivity to intestinal bacterial antigens [36,37], and impairs the balance of intestinal mucosal immunity to inflammatory injury followed by lymphocytic infiltration of the intestinal mucosa $[38,39]$. CD4 + CD25 + Foxp3 + T cells increased in the colon of patients with UC [40]. These data indicated that Tregs would be a promising target for treating UC, because increasing the activ- 
ity of appropriate Tregs in the gut should help to restore inflamed colonic tissues [41]. Then, although IL-10 and TGF- $\beta$ are good representative of Tregs, to support the conclusions concerning the effects of the mentioned probiotics on Treg cells in this study it could be good to show increasing the frequency of the Treg population by known markers, such as Foxp3.

Furthermore, evidence has suggested that probiotic bacteria may have, in a species- or even strain-dependent manner, a potential use as anti-inflammatory agents which exert their effect by stimulation of Tregs [42]. Hence, in this study we tried to check if B. lactis, L. acidophilus or both have any effect on the Tregs of UC patients by measuring IL-10 and TGF- $\beta$. Although the results indicate that $B$. lactis, compared to L. acidophilus, had more stimulatory effect on Tregs of UC patients but it still stimulates, even less than Lactobacillus acidophilus, the effector Th cells (by augmenting TNF- $\alpha$ and IFN- $\gamma$ ) compared to control. Since it has been shown that each metabolic product or body fraction of probiotic bacteria could have its individual effect on immune system [43], it is suggested to fractionate B. lactis and check the individual effect of each metabolic product or trunk of the bacterium on Tregs of UC patients.

In conclusion, each of these 2 probiotics or their mixed could have individual modulatory impact on immune system including Treg/effector Th of UC patients. Because UC patients suffer from an aggressive intestinal mucosal inflammatory response, researchers are seeking for probiotic bacteria which potentiate Treg activity to suppress the effector Th cells in UC patients. Thus from these 2 selected probiotics in this study, B. lactis as one of the probiotic sources of yogurt, which had more stimulatory effect on Tregs of UC patients, albeit still stimulates the effector Th cells could be a good potential therapeutic candidate for further investigation.

\section{Acknowledgments}

$\nabla$

This work was financially supported by Dezful University of Medical Sciences, Dezful, Iran and Sherkat Pegah Khuzestan, Dezful, Iran.

\section{Declaration of Interest \\ $\nabla$}

The authors declare no conflicts of interest.

\footnotetext{
Affiliations

Department of Immunology, Faculty of Medicine, Dezful University of Medical Sciences, Dezful, Iran

Cellular and Molecular Immunology Research laboratory, Faculty of

Medicine, Dezful University of Medical Sciences, Dezful, Iran

Sherkat Pegah Khoozestan, Dezful, Iran

${ }^{4}$ Tehran Chemie Pharmaceutical Company, Tehran, Iran

Department of Immunology, School of Medicine, Kerman University of

Medical Sciences, Kerman, Iran

${ }^{6}$ Department of Microbiology, Azad University, Boroujerd, Iran

Department of Microbiology, Azad University, Arak, Iran

${ }^{8}$ Department of Internal Medicine, School of Medicine, Dezful University of

Medical Sciences, Dezful, Iran
}

\section{References}

1 Molodecky NA, Soon IS, Rabi DM et al. Increasing incidence and prevalence of the inflammatory bowel diseases with time, based on systematic review. Gastroenterology 2012; 142: 46-54 e42

2 Podolsky DK. Inflammatory bowel disease. N Engl J Med 2002; 347: 417-429

3 Zoetendal EG, Rajilic-Stojanovic M, de Vos WM. High-throughput diversity and functionality analysis of the gastrointestinal tract microbiota. Gut 2008; 57: 1605-1615

4 Meydani SN, $\mathrm{Ha}$ WK. Immunologic effects of yogurt. Am J Clin Nutr 2000; 71: 861-872 Review

5 Sartor RB. Therapeutic manipulation of the enteric microflora in inflammatory bowel diseases: antibiotics, probiotics, and prebiotics. Gastroenterology 2004; 126: 1620-1633

6 Campieri M, Gionchetti P. Probiotics in inflammatory bowel disease: new insight to pathogenesis or a possible therapeutic alternative? Gastroenterology 1999; 116: 1246-1249

7 Niers LE, Timmerman HM, Rijkers GT et al. Identification of strong interleukin-10 inducing lactic acid bacteria which downregulate $\mathrm{T}$ helper type 2 cytokines. Clin Exp Allergy 2005; 35: 1481-1489

8 Hirahara K, Poholek A, Vahedi G et al. Mechanisms underlying helper T-cell plasticity: implications for immune-mediated disease. J Allergy Clin Immunol 2013; 131: 1276-1287

9 Yamane H, Paul WE. Early signaling events that underlie fate decisions of naive $\mathrm{CD} 4(+)$ T cells toward distinct T-helper cell subsets. Immunol Rev 2013; 252: 12-23

10 Lavasani S, Dzhambazov B, Nouri M et al. A novel probiotic mixture exerts a therapeutic effect on experimental autoimmune encephalomyelitis mediated by IL-10 producing regulatory T cells. PLOS ONE 2010; 5: 1-11

11 Dahlén R, Magnusson MK, Bajor A et al. Global mucosal and serum cytokine profile in patients with ulcerative colitis undergoing antiTNF therapy. Scand J Gastroenterol. 2015; 16: 1-9

12 Ghouri YA, Richards DM, Rahimi EF et al. Systematic review of randomized controlled trials of probiotics, prebiotics, and synbiotics in inflammatory bowel disease. Clin Exp Gastroenterol 2014; 9: 473-487 Review

13 Berg D, Clemente JC, Colombel JF. Can inflammatory bowel disease be permanently treated with short-term interventions on the microbiome? Expert Rev Gastroenterol Hepatol 2015; 10: 1-15

14 Sheikhi A, Saadati K, Jafarzadeh A et al. Augmenting the expression of NKp44 molecule and the natural killer activity in peripheral blood mononuclear cells from patients with malignant colorectal carcinoma. Drug Res (Stuttg) 2014; 64: 281-286

15 Sheikhi A, Saadati K, Salmani $R$ et al. In vitro modulation of natural killer activity of human peripheral blood mononuclear cells against prostate tumor cell line. Immunopharmacol Immunotoxicol 2011; 33: 700-708

16 Sheikhi A, Nazarian M, Khadem-Al-Melleh A et al. In-vitro effects of Mycobacterium bovis BCG-lysate and its derived heat shock proteins on cytokines secretion by blood mononuclear cells of rheumatoid arthritis patients in comparison with healthy controls. Int Immunopharmacol 2008; 8: 887-892

17 Amirghofran Z, Sheikhi AK, Kumar PV et al. Soluble HLA class I molecules in malignant pleural and peritoneal effusions and its possible role on NK and LAK cytotoxicity. J Cancer Res Clin Oncol 2002; 128: 443-448

18 Fuss IJ, Neurath $M$, Boirivant $M$ et al. Disparate CD4+lamina propria (LP) lymphokine secretion profiles in inflammatory bowel disease. Crohn's disease LP cells manifest increased secretion of IFNgamma, whereas ulcerative colitis LP cells manifest increased secretion of IL-5. J Immunol 1996; 157: 1261-1270

19 Heller F, Florian P, Bojarski $C$ et al. Interleukin-13 is the key effector Th2 cytokine in ulcerative colitis that affects epithelial tight junctions, apoptosis, and cell restitution. Gastroenterology 2005; 129: 550-564

20 Strober W, Fuss I, Mannon P. The fundamental basis of inflammatory bowel disease. J Clin Invest 2007; 117: 514-521

21 Abraham C, Medzhitov R. Interactions between the host innate immune system and microbes in inflammatory bowel disease. Gastroenterology $2011 ; 140: 1729-1737$

22 Danese S. Immune and nonimmune components orchestrate the pathogenesis of inflammatory bowel disease. Am J Physiol Gastrointest Liver Physiol 2011; 300: G716-G722

23 Hanauer SB. Medical therapy for ulcerative colitis. Gastroenterology 2004; 126: 1582-1592

24 Zheng $B$, van Bergenhenegouwen J, Overbeek $S$ et al Bifidobacterium breve attenuates murine dextran sodium sulfate-induced colitis and increases regulatory $\mathrm{T}$ cell responses. PLoS One 2014; 9: e95441 
25 Imaoka A, Shima T, Kato $K$ et al. Anti-inflammatory activity of probiotic Bifidobacterium: Enhancement of IL-10 production in peripheral blood mononuclear cells from ulcerative colitis patients and inhibition of IL-8 secretion in HT-29 cells. World J Gastroenterol 2008; 14: 2511-2516

26 Kato K, Mizuno S, Umesaki Y et al. Randomized placebo-controlled trial assessing the effect of bifidobacteria-fermented milk on active ulcerative colitis. Aliment Pharmacol Ther 2004; 20: 1133-1141

27 Peran L, Camuesco D, Comalada M et al. A comparative study of the preventative effects exerted by three probiotics, Bifidobacterium lactis, Lactobacillus casei and Lactobacillus acidophilus, in the TNBS model of rat colitis. J Appl Microbiol 2007; 103: 836-844

28 Ohman L, Dahlen R, Isaksson $S$ et al. Serum IL-17A in newly diagnosed treatment-naive patients with ulcerative colitis reflects clinical disease severity and predicts the course of disease. Inflamm Bowel Dis 2013; 19: 2433-2439

29 Rismo R, Olsen T, Cui G et al. Mucosal cytokine gene expression profiles as biomarkers of response to infliximab in ulcerative colitis. Scand J Gastroenterol 2012; 47: 538-547

30 Olsen T, Goll R, Cui G et al. Tissue levels of tumor necrosis factor-alpha correlates with grade of inflammation in untreated ulcerative colitis. Scand J Gastroenterol 2007; 42: 1312-1320

31 Rodriguez-Peralvarez ML, Garcia-Sanchez V, Villar-Pastor CM et al. Role of serum cytokine profile in ulcerative colitis assessment. Inflamm Bowel Dis 2012; 18: 1864-1871

32 Holmen N, Lundgren A, Lundin S et al. Functional CD4 + CD25 high regulatory $\mathrm{T}$ cells are enriched in the colonic mucosa of patients with active ulcerative colitis and increase with disease activity. Inflamm Bowel Dis 2006; 12: 447-456

33 Olsen T, Cui G, Goll $R$ et al. Infliximab therapy decreases the levels of TNF-alpha and IFN-gamma mRNA in colonic mucosa of ulcerative colitis. Scand J Gastroenterol 2009; 44: 727-735
34 Hassan C, Ierardi E, Burattini O et al. Tumour necrosis factor alpha downregulation parallels inflammatory regression in ulcerative colitis patients treated with infliximab. Dig Liver Dis 2007; 39: 811-817

35 Masuda H, Iwai S, Tanaka T et al. Expression of IL-8, TNF-alpha and IFN-gamma m-RNA in ulcerative colitis, particularly in patients with inactive phase. J Clin Lab Immunol 1995; 46: 111-123

36 Singh B, Read S, Asseman C et al. Control of intestinal inflammation by regulatory T cells. Immunol Rev 2001; 182: 190-200

37 Mottet C, Uhlig HH, Powrie F. Cutting edge: cure of colitis by CD4+CD25 + regulatory T cells. J Immunol 2003; 170: 3939-3943

38 Uhlig HH, Coombes J, Mottet C et al. Characterization of Foxp3 $+\mathrm{CD} 4+\mathrm{CD} 25+$ and IL-10-secreting CD4 $+\mathrm{CD} 25+\mathrm{T}$ cells during cure of colitis. J Immunol 2006; 177: 5852-5860

39 Bacchetta R, Passerini L, Gambineri E et al. Defective regulatory and effector T cell functions in patients with FOXP3 mutations. J Clin Invest 2006; 116: 1713-1722

40 McMurchy AN, Di Nunzio S, Roncarolo MG et al. Molecular regulation of cellular immunity by FOXP3. Adv Exp Med Biol 2009; 665: 30-46

41 Himmel ME, Yao Y, Orban PC et al. Regulatory T-cell therapy for inflammatory bowel disease: more questions than answers. Immunology 2012; 136: 115-122

42 Pronio A, Montesani C, Butteroni C et al. Probiotic administration in patients with ileal pouch-anal anastomosis for ulcerative colitis is associated with expansion of mucosal regulatory cells. Inflamm Bowel Dis 2008; 14: 662-668

43 Al-Hassi HO, Mann ER, Sanchez B et al. Altered human gut dendritic cell properties in ulcerative colitis are reversed by Lactobacillus plantarum extracellular encrypted peptide STp. Mol Nutr Food Res 2014; 58: $1132-1143$ 